Annals of Plant and Soil Research 23(1): 42-47 (2021)

https://doi.org/10.47815/apsr.2021.10027

\title{
Productivity, nutrients uptake and quality of forage oat (Avena sativa) and residual soil fertility as influenced by nitrogen and FYM
}

\author{
MANOJ PANDEY AND OMPAL SINGH
}

\begin{abstract}
Department of Agricultural Chemistry and Soil Science, Raja Balwant Singh College (Dr B R Ambedkar University) Bichpuri, Agra (U.P.) 283105
\end{abstract}

Received: October, 2020; Revised accepted: December, 2020

\begin{abstract}
A field experiment was conducted during rabi season (2014-16) at Research Farm, R.B.S. College, Bichpuri, Agra (U.P.) to study the effect of nitrogen and FYM levels on growth, yield and uptake of nutrients in oat (Avena sativa L.) and soil fertility. The experiment was laid out in randomized block design with four levels of nitrogen $\left(0,50,100\right.$ and $\left.150 \mathrm{~kg} \mathrm{ha}^{-1}\right)$ and three levels of $F Y M\left(0,5\right.$ and $\left.10 \mathrm{th} \mathrm{h}^{-1}\right)$ with three replications. The results revealed that the plant height, yields of oat crop increased significantly up to $150 \mathrm{~kg} \mathrm{~N}$ and $10 \mathrm{t} \mathrm{FYM} \mathrm{ha}^{-1}$ over control. The maximum values of green foliage (447.16 and 414,03 qha ${ }^{-1}$ ) and dry matter yield (64.98 and $60.30 \mathrm{q} \mathrm{ha}^{-1}$ ) were recorded with $150 \mathrm{~kg} \mathrm{~N}$ and $10 \mathrm{t} \mathrm{FYM} \mathrm{ha}{ }^{-1}$, respectively. The application of FYM alone was also found to be more beneficial in terms of growth and yield of oat crop over control. The interaction effect between $150 \mathrm{~kg} \mathrm{~N}^{-1}$ and 10 t FYM ha ${ }^{-1}$ recorded maximum yield than other treatment combination. The maximum content (14.14 and $14.10 \%$ ) and yield of protein in oat crop (920.6 and $853.5 \mathrm{~kg} \mathrm{ha}^{-1}$ ) were recorded with $150 \mathrm{~kg} \mathrm{~N}$ and 10 t FYM ha ${ }^{-1}$ but maximum value of crude fiber (32.96 and $33.7 \%$ ) were recorded under control, respectively. However, crude fiber content in oat was not affected significantly with $N$ and FYM levels. The uptake of major (N,P and K) and micronutrients ( $\mathrm{Fe}, \mathrm{Mn}, \mathrm{Cu}$ and $\mathrm{Zn}$ ) by oat crop increased significantly with the levels of nitrogen up to $150 \mathrm{~kg} \mathrm{ha}^{-1}$ and FYM $10 \mathrm{tha}^{-1}$, respectively. The status of organic carbon and available nutrients in post harvest soil improved with $150 \mathrm{~kg} \mathrm{~N}$ and $10 \mathrm{t} \mathrm{FYM} \mathrm{ha}{ }^{-1}$. The minimum amounts of available nutrients in post harvest soil were recorded under control treatment.
\end{abstract}

Key words: Oat, nitrogen, FYM, quality, uptake of nutrients, soil fertility, yield

\section{INTRODUCTION}

Oat (Avena sativa L.) is an important cereal mainly for fodder during rabi season. Oats rank fourth in importance among cereals exceeded only by wheat, rice and maize. It is high in protein, fat, vitamin $B$, and minerals such as phosphorus and iron. Oat flour is used in the formulation of a skin care baby powder and as preservative. Oat provides a very nutritious fodder (protein 13- 15\%) especially suited to milch animals. The ever-rising demand for fodder and feed for sustaining livestock production can be met through increasing productivity of fodder. The profitable production of oat crop may be affected by many factors, among these soil fertility to produce good fodder and seed, is of practical significance. The poor yield of oat crop in our country is mainly ascribed to low fertility of soil, inadequate manuring and cultural practices. An optimum supply of nitrogen is important for vigorous vegetative growth, chlorophyll formation and carbohydrate utilization. But $\mathrm{N}$ use efficiency in cereals is quite low. Conjoint use of inorganic and organic sources of $\mathrm{N}$ is recommended to maintain soil and crop productivity. The integrated $\mathrm{N}$ management also increased organic carbon content and availability of plant nutrients in soil. Integration of chemical and organic sources and their efficient management have shown promising results not only in sustaining the production but also in maintaining soil heath (Singh et al. 2016, Singh and Patra2017), Pandey (2018) and Pandey et al.( 2020) suggested that further improvement in nutrient use efficiency will become possible by balanced use of N, P and $\mathrm{K}$ fertilizers and by rational use of organic manures in the crops. The role of organic matter is well established in governing the nutrient fluxes, microbial biomass and improvement in soil physical, chemical and biological properties. Extra mining or nutrients will have to be resisted in order to maintain the soil health. Maintaining soil health is most important to ensure food and nutritional security of the country. However, there is a lack of information regarding the performance of FYM and nitrogen in relation to productivity and 
fertility of soil under oat cultivation in Agra region. Therefore, a study was conducted to assess the effect of nitrogen and FYM on yield and uptake of nutrients in fodder oat.

\section{MATERIALS AND METHODS}

A field experiment was carried out at Research Farm, Raja Balwant Singh College, Bichpuri (Agra) during rabi season of 2014-15 and 2015-16. The site of this experiment is located at $27^{\circ} 2^{\prime} \mathrm{N}$ latitude and $77^{\circ} 9^{\prime} \mathrm{E}$ longitude at an altitude of 168 meter above the mean sea level. The experimental site is characterized by semi-arid climate with hot dry summers (46 to $\left.48^{\circ} \mathrm{C}\right)$ and very low temperature during winter (as low as $2^{\circ} \mathrm{C}$ ). The average value of PET is about $5.66 \mathrm{~mm}$ /day with a maximum of $10.17 \mathrm{~mm} /$ day. The rainfall in this region is received from southwest monsoon. The probability of onset of monsoon is first week of July and it ends by third week of September. The average rainfall is about 650 $\mathrm{mm}$ of which a major portion of $546 \mathrm{~mm}(84 \%)$ is received from July to September and only $104 \mathrm{~mm}(16 \%)$ is received in the remaining part of the year. The experimental soil was sandy loam in texture having $\mathrm{pH} 8.0$, organic carbon $3.8 \mathrm{~g} \mathrm{~kg}^{-1}$, available $\mathrm{N} 165 \mathrm{~kg} \mathrm{ha}^{-1}$, available $P 10.2 \mathrm{~kg} \mathrm{ha}{ }^{1}$, available $\mathrm{K} 130 \mathrm{kgha}^{1}$, available $S 16.5 \mathrm{~kg} \mathrm{ha}{ }^{1}$, DTPA - iron $4.6 \mathrm{mg}$ $\mathrm{kg}^{1}$, manganese $2.2 \mathrm{mg} \mathrm{kg}^{1}$ copper $2.3 \mathrm{mg} \mathrm{kg}$ ${ }^{1}$ and zinc $0.57 \mathrm{mg} \mathrm{kg}^{1}$. The experiment was laid out in randomized block design with three replications. The treatments consisted of four levels of $N\left(0,50,100\right.$ and $\left.150 \mathrm{~kg} \mathrm{ha}^{-1}\right)$ and three levels of $\operatorname{FYM}\left(0,5\right.$ and $\left.10 \mathrm{t} \mathrm{ha}^{-1}\right)$. Nitrogen was supplied in the form of urea as per treatments. Single superphosphate and muriate of potash were used as sources for $\mathrm{P}_{2} \mathrm{O}_{5}$ and $\mathrm{K}_{2} \mathrm{O}$, respectively. Recommended dose of $P$ and $\mathrm{K}$ for oat was 60 and $40 \mathrm{~kg} \mathrm{ha}^{-1}$, respectively. Full quantities of $P$ and $K$ fertilizers were given at the time of sowing. Nitrogen was applied as basal and two splits at first and second irrigation. Well-decomposed FYM was added to the plots as per treatment one week before sowing. The oat (variety Kant) was sown at the rate of $80 \mathrm{~kg} \mathrm{ha}^{-1}$ in first weak of November in both the years. The oat crop was irrigated at the proper time as judged by the appearance of soil and the crop. The yield of oat was recorded after harvest than processed samples of were digested using di-acid mixture of $\mathrm{HNO}_{3}: \mathrm{HClO}_{4}(10: 4)$. The estimation of $\mathrm{Fe}$, $\mathrm{Mn}, \mathrm{Cu}$ and $\mathrm{Zn}$ in acid extract was done using AAS. Phosphorus, $\mathrm{K}$ and $\mathrm{S}$ were determined by vanadomolybdo phosphoric yellow colour method, flame photometer (Jackson 1973), turbidimetric method (Chesnin and Yien, 1951), respectively. Nitrogen content was estimated by modified Kjeldahl method and crude protein content was calculated by multiplying $\mathrm{N}$ content with a factor of 6.25. The uptake of nutrients by oat crop was worked out by multiplying their content values with corresponding yield data. After harvest of the crop, soil samples were collected and analyzed for available N (Subbiah and Asija, 1956), P (Olsen et al. 1954), K (1 N ammonium acetate extractable, Hanway and Hiedel, 1952), S (0.15\% $\mathrm{CaCl}_{2}$ extractable), DTPA extractable $\mathrm{Fe}, \mathrm{Mn}, \mathrm{Cu}$ and $\mathrm{Zn}$ (Lindsay and Norvell, 1978). The trend of results was similar during both the years hence; data were subjected to pooled analysis for results and discussion.

\section{RESULTS AND DISCUSCUSION}

\section{Growth and yield}

The results indicated that the plant height increased significantly with nitrogen application over control and tallest plants were noted under $150 \mathrm{~kg} \mathrm{~N} \mathrm{ha}^{-1}$. Plant height increased from 96.3 $\mathrm{cm}$ at control to $105.0 \mathrm{~cm}$ at $150 \mathrm{~kg} \mathrm{~N} \mathrm{ha}^{-1}$ level. These results are in close conformity with the findings of Pandey etal.(2020) It can be ascribed to the better nutritional rhizospheric environment for growth and development of crop. Plant height of oat crop also increased significantly with FYM application over control. Plant height increased from $97.6 \mathrm{~cm}$ at control to $104.2 \mathrm{~cm}$ at $10 \mathrm{t} \mathrm{FYM}$ $\mathrm{ha}^{-1}$ (Table1). The beneficial effect of FYM on plant height may be attributed to its contribution in supplying additional plant nutrients, improvement in soil physical condition and biological process in soil. Similar results have been reported by Kumar et al.(2015) and Singh et al. (2016). The interaction effect of $N$ and FYM on plant height was found to be significant and maximum value of plant height was recorded under $150 \mathrm{~kg} \mathrm{~N}+10$ t FYM ha ${ }^{-1}$. 
Table1: Effect of nitrogen and FYM levels on plant height, yield, dry matter yield, and quality of oat (mean of 2 years)

\begin{tabular}{c|c|c|c|c|c|c|}
\hline Treatment & $\begin{array}{c}\text { Plant height } \\
(\mathrm{cm})\end{array}$ & $\begin{array}{c}\text { Green Foliage } \\
\text { yield }\left(\mathrm{qha}^{-1}\right)\end{array}$ & $\begin{array}{c}\text { Dry matter yield } \\
\left(\mathrm{q} \mathrm{ha}^{-1}\right)\end{array}$ & $\begin{array}{c}\text { Protein } \\
\text { content }(\%)\end{array}$ & $\begin{array}{c}\text { Protein yield } \\
\left(\mathrm{kgha}^{-1}\right)\end{array}$ & $\begin{array}{c}\text { Crude Fiber } \\
(\%)\end{array}$ \\
\hline Nitrogen $\left(\mathrm{kgha}^{-1}\right)$ & & & & & \\
0 & 96.3 & 319.04 & 46.84 & 12.99 & 609.9 & 32.96 \\
50 & 99.6 & 354.41 & 51.69 & 13.62 & 705.6 & 32.73 \\
100 & 102.2 & 402.31 & 58.30 & 13.93 & 813.9 & 32.5 \\
150 & 105.0 & 447.16 & 64.98 & 14.14 & 920.6 & 32.16 \\
$\mathrm{C}(\mathrm{P}=0.05)$ & 2.82 & 14.58 & 3.93 & 0.26 & 81.5 & $\mathrm{NS}$ \\
FYM (t ha $\left.{ }^{-1}\right)$ & & & & & & \\
0 & 97.6 & 344.06 & 50.11 & 13.23 & 665.8 & 33.7 \\
5 & 100.6 & 384.11 & 55.95 & 13.68 & 768.3 & 32.6 \\
10 & 104.2 & 414.03 & 60.30 & 14.10 & 853.5 & 32.1 \\
SEM \pm & 0.8 & 4.39 & 1.18 & 0.06 & 24.5 & 0.32 \\
$\mathrm{CD}(\mathrm{P}=0.05)$ & 2.44 & 12.77 & 3.43 & 0.17 & 71.3 & $\mathrm{NS}$ \\
$\mathrm{N} \mathrm{X} \mathrm{FYM}$ & 4.95 & 25.27 & 6.25 & 0.44 & 150.0 & $\mathrm{NS}$ \\
\hline
\end{tabular}

The increase in green foliage yield at each level of nitrogen addition was found to be significant as compared to control and maximum yield $\left(447.16 \mathrm{q} \mathrm{ha}^{-1}\right)$ was recorded with $150 \mathrm{~kg} \mathrm{~N}$ ha-1. The per cent increases in green foliage yield over control were $11.1,26.1$ and 40.2 , respectively with 50,100 and $150 \mathrm{~kg} \mathrm{~N} \mathrm{ha}^{-1}$ level of nitrogen. As green foliage yield is primarily a function of cumulative effect of plant growth characters i.e. plant height, the higher value of this character can be assigned as the most probable reason for significantly higher green foliage yield. Similar results were also reported by Pandey and Singh (2017) and Sikarwar et al. (2018). Application of FYM to oat crop proved useful in enhancing the green foliage yield. The mean green foliage yield of oat rose from 344.06 $\mathrm{q} \mathrm{ha}^{-1}$ in the control to $414.03 \mathrm{q} \mathrm{ha}^{-1}$ with $10 \mathrm{t}$ FYM $\mathrm{ha}^{-1}$. Increases in average green foliage yield due to 5.0 and $10 \mathrm{t} \mathrm{FYM} \mathrm{ha}^{-1}$ were recorded to the tune of 11.6 and 20.3 percent, respectively over control. This may be attributed to better growth due to addition of FYM. Similar results have been reported by Singh et al. (2016), Singh and Patra(2017) and Pandey (2018).

The dry matter yield of oat also improved with nitrogen application and maximum yield of dry matter $\left(64.98 \mathrm{q} \mathrm{ha}^{-1}\right)$ was recorded at $150 \mathrm{~kg}$ $\mathrm{N}$ ha ${ }^{-1}$. The dry matter yield of oat increased from $46.84 \mathrm{q} \mathrm{ha}^{-1}$ at control to $64.98 \mathrm{q} \mathrm{ha}^{-1}$ with $150 \mathrm{~kg} \mathrm{~N} \mathrm{ha}^{-1}$. The increases in dry matter yield due to 50,100 and $150 \mathrm{~kg} \mathrm{~N}^{-1}$ levels over control were 10.3, 24.5 and $38.7 \%$, respectively. Similar results were also reported by Pandey and Singh (2017). The FYM levels had a positive effect on dry matter yield over control. Application of 5 and 10 t FYM ha $^{-1}$ increased the dry matter yield by 11.5 and $20.3 \%$ over control, respectively. Similar results were reported by Singh and Patra (2017). Application of FYM along with nitrogen proved superior in terms of dry matter yield of oat crop. The maximum yield of dry matter was recorded under $150 \mathrm{~kg} \mathrm{~N}+10$ t FYM ha ${ }^{-1}$ treatment (Pandey (2018).

\section{Quality}

The protein content in oat increased from $12.99 \%$ at control to $14.14 \%$ with $150 \mathrm{~kg}$ $\mathrm{N}$ ha $^{-1}$. Obviously, protein content is directly related to nitrogen content in the material. Pandey (2018) also reported similar results. Protein content in oat with both the FYM levels was significantly higher than control. The amount of protein content in oat increased from $13.23 \%$ at control to $14.10 \%$ at $10 \mathrm{t} \mathrm{FYM} \mathrm{ha}^{-1}$. Singh and Patra (2017) also reported similar results. Thus, the results showed synergistic effect of applied FYM on protein content in foliage crop. The maximum value of protein yield was noted under $150 \mathrm{~kg} \mathrm{~N} \mathrm{ha}^{-1}$. Nitrogen application increased the protein content in oat plants therefore protein yield also increased. Similar results were also reported by Pandey and Singh (2017). The addition of FYM also enhanced the protein yield of oat plants significantly over control. As compared to control, both the levels of FYM were proved significantly superior in respect of protein yield of oat. The maximum value of 
protein yield was recorded under $150 \mathrm{~kg} \mathrm{~N}+10 \mathrm{t}$ FYM ha ${ }^{-1}$ indicating significant interaction effect of $\mathrm{N}$ and $\mathrm{FYM}$ on the protein yield of oat ( Pandey , 2018 ). The crude fiber content in oat plants was not affected significantly by various levels of nitrogen and FYM. However, the minimum and maximum values of crude fiber were recorded with $150 \mathrm{~kg} \mathrm{~N}+10 \mathrm{t} \mathrm{FYM} \mathrm{ha}^{-1}$ and control, respectively. Addition of FYM did not affect the crude fiber content significantly over control. Pandey (2018) and Pandey et al. (2020) also reported similar results.

Table 2: Effect of nitrogen and FYM levels on $\mathrm{N}, \mathrm{P}, \mathrm{K}, \mathrm{S}\left(\mathrm{kg} \mathrm{ha}^{-1}\right) \mathrm{Fe}, \mathrm{Mn}, \mathrm{Cu}$ and $\mathrm{Zn}\left(\mathrm{g} \mathrm{ha}^{-1}\right.$ ) uptake of oat (mean of 2 years)

\begin{tabular}{c|c|c|c|c|c|c|c|c|}
\hline Treatment & $\mathrm{N}$ & $\mathrm{P}$ & $\mathrm{K}$ & $\mathrm{S}$ & $\mathrm{Fe}$ & $\mathrm{Mn}$ & $\mathrm{Cu}$ & $\mathrm{Zn}$ \\
\hline Nitrogen $_{\left(\mathrm{kgha}^{-1}\right)}$ & & & & & & & & \\
0 & 97.5 & 7.0 & 87.4 & 8.7 & 366.1 & 152.0 & 18.9 & 148.9 \\
50 & 112.8 & 8.4 & 97.3 & 10.4 & 418.0 & 173.0 & 20.5 & 159.2 \\
100 & 130.2 & 10.5 & 110.7 & 12.6 & 482.4 & 202.7 & 22.8 & 166.1 \\
150 & 147.2 & 12.5 & 124.0 & 15.8 & 558.5 & 234.7 & 26.1 & 169.7 \\
$\mathrm{SEm} \pm$ & 3.42 & 0.36 & 2.46 & 0.93 & 14.7 & 7.35 & 0.99 & 2.62 \\
$\mathrm{C}(\mathrm{P}=0.05)$ & 9.95 & 1.04 & 7.24 & 2.71 & 42.8 & 21.39 & 2.89 & 7.63 \\
& & & & & & & & \\
FYM $\left(\mathrm{t} \mathrm{ha}^{-1}\right)$ & 106.4 & 7.8 & 91.6 & 9.7 & 392.1 & 161.2 & 17.8 & 132.9 \\
0 & 122.9 & 9.6 & 106.5 & 12.1 & 462.2 & 189.8 & 22.5 & 161.9 \\
10 & 136.5 & 11.5 & 116.4 & 13.8 & 518.1 & 220.8 & 26.0 & 188.2 \\
$\mathrm{SEm} \pm$ & 2.95 & 0.30 & 2.08 & 0.78 & 12.9 & 6.45 & 0.86 & 2.27 \\
$\mathrm{CD}(\mathrm{P}=0.05)$ & 8.59 & 0.87 & 6.12 & 2.27 & 37.5 & 18.76 & 2.50 & 6.67 \\
\hline
\end{tabular}

\section{Uptake of nutrients}

The uptake of nitrogen by oat crop significantly increased with increasing levels of nitrogen and FYM. The plants treated with 150 $\mathrm{kg} \mathrm{N} \mathrm{ha}^{-1}$ dose removed the maximum amount of nitrogen from the soil. Addition of lower levels of $\mathrm{N}$ also helped in removing significantly more amounts of nitrogen by plants over control. Higher values of nitrogen uptake are apparently the result of favorable effect of these treatments on nitrogen absorption coupled with greater yields. Goswami and Pandey (2018) also reported similar results. The application of FYM contributed to significant increased the $\mathrm{N}$ uptake by oat crop. The mean $\mathrm{N}$ uptake by oat crop increased from 106.4 to $136.5 \mathrm{~kg} \mathrm{ha}^{-1}$ as the levels of FYM increased from 0 to $10 \mathrm{t} \mathrm{ha}^{-1}$. Singh et al. (2016) also reported similar results in oat. The nitrogen and FYM application to the soil increased significantly the uptake of phosphorus by oat crop over control. The maximum value of $P\left(12.5\right.$ and $\left.11.5 \mathrm{~kg} \mathrm{ha}^{-1}\right)$ uptake was recorded under $150 \mathrm{~kg} \mathrm{~N}$ and $10 \mathrm{t}$ FYM ha ${ }^{-1}$, respectively. The effect of nitrogen and FYM application in increasing phosphorus uptake may be associated with physiological stimulation of plant rather than increased ramification of root system. These results are in agreement with those reported by Singh et al. (2016) in oat crop. The potassium uptake by oat crop increased significantly with increasing levels of nitrogen and FYM over control. The K uptake increased from 87.4 to 124.0 and 91.6 to $116.4 \mathrm{~kg} \mathrm{ha}^{-1}$ with $150 \mathrm{~kg} \mathrm{~N}$ and $10 \mathrm{t} \mathrm{FYM} \mathrm{ha}^{-1}$, respectively. This increase in $\mathrm{K}$ uptake may be attributed to increased dry matter production of oat with $\mathrm{N}$ and FYM application. Similar results were reported by Singh et al. (2016) in oat crop. The nitrogen application influenced the uptake of sulphur by oat crop significantly over control. The variation between levels of $\mathrm{N}$ was also significant. The maximum value of sulphur uptake by oat crop was recorded with $150 \mathrm{~kg} \mathrm{~N}$ $\mathrm{ha}^{-1}$. Application of FYM tended to increase the $\mathrm{S}$ uptake significantly over control. The $\mathrm{S}$ uptake increased from 9.7 to $13.8 \mathrm{~kg}$ ha-1 with $10 \mathrm{t}$ FYM $\mathrm{ha}^{-1}$ application. This increase may be ascribed to an enhanced dry matter production of oat with FYM application. Pandey (2018) also reported similar results. The uptake of Fe by oat crop also increased with $\mathrm{N}$ application over control, which may be attributed to increased dry matter yield with $\mathrm{N}$ application. Uptake of $\mathrm{Fe}$ also increased with FYM application over control. The iron uptake increased from 392.1 to $518.1 \mathrm{~g} \mathrm{ha}^{-1}$ with $10 \mathrm{t} \mathrm{FYM} \mathrm{ha}^{-1}$. Application of nitrogen increased the average Mn uptake by oat crop up to $150 \mathrm{~kg}$ 
$\mathrm{N} \mathrm{ha}^{-1}$. Each higher level of applied nitrogen had a beneficial effect on Mn uptake by oat crop. The results showed a synergistic effect of $\mathrm{N}$ addition on $\mathrm{Mn}$ uptake by plants. The uptake of $\mathrm{Mn}$ by oat crop increased with FYM application over control due to increase in dry matter yield. Singh and Patra (2017) and Pandey (2018) also reported similar results. Application of $\mathrm{N}$ significantly increased the average copper uptake by oat plants. Each level of applied $\mathrm{N}$ had a significantly beneficial effect on $\mathrm{Cu}$ uptake by oat crop. This increase in $\mathrm{Cu}$ uptake with $\mathrm{N}$ addition may be ascribed to greater dry matter production. Similar results were reported by Pandey (2018). The results indicate that the uptake of copper by oat plants increased with FYM application over control due to increase in dry matter yield. There was a consistent increase in $\mathrm{Zn}$ uptake with increasing $\mathrm{N}$ levels up $150 \mathrm{~kg} \mathrm{~N} \mathrm{ha}^{-1}$. The $\mathrm{Zn}$ uptake increased from $148.9 \mathrm{~g} \mathrm{ha}^{-1}$ at control to $169.7 \mathrm{~g} \mathrm{ha}^{-1}$. Zinc uptake by oat increased significantly with FYM addition to the soil. The increase in $\mathrm{Zn}$ uptake by oat crop was from $132.9 \mathrm{~g} \mathrm{ha}^{-1}$ to $188.2 \mathrm{~g} \mathrm{ha}^{-1}$ with $10 \mathrm{t} \mathrm{FYM} \mathrm{ha}^{-1}$ soil. This increase in Zn uptake may be ascribed to the higher production of oat as well as improvement in $\mathrm{Zn}$ content with FYM addition. The beneficial effect of farmyard manure on $\mathrm{Zn}$ uptake may be due to its contribution in supplying additional plant nutrients, improvement of soil physical conditions and biological process in soil (Singh et al.2016).

Table 3: Effect of nitrogen and FYM levels on status of available nutrients in soil after harvest of oat (mean of 2 years)

\begin{tabular}{|c|c|c|c|c|c|c|c|c|c|}
\hline Treatment & $\underset{\left(\mathrm{gkg}^{-1}\right)}{\mathrm{OC}}$ & $\begin{array}{c}\mathrm{N} \\
\left(\mathrm{kg} \mathrm{ha}^{-1}\right)\end{array}$ & $\begin{array}{c}\mathrm{P} \\
\left(\mathrm{kgha}^{-1}\right)\end{array}$ & $\begin{array}{c}\mathrm{K} \\
\left(\mathrm{kgha}^{-1}\right)\end{array}$ & $\begin{array}{c}\mathrm{S} \\
\left(\mathrm{kgha}^{-1}\right)\end{array}$ & $\begin{array}{c}\mathrm{Fe} \\
\left(\mathrm{mgkg}^{-1}\right)\end{array}$ & $\begin{array}{c}\mathrm{Mn} \\
\left(\mathrm{mgha}^{-1}\right)\end{array}$ & $\begin{array}{c}\mathrm{Cu} \\
\left(\mathrm{mghkg}^{1}\right)\end{array}$ & $\begin{array}{c}\mathrm{Zn} \\
\left(\mathrm{mgkg}^{-1}\right)\end{array}$ \\
\hline \multicolumn{10}{|l|}{ Nitrogen $\left(\mathrm{kgha}^{-1}\right)$} \\
\hline 0 & 3.8 & 148.7 & 9.8 & 120.3 & 14.6 & 4.3 & 2.0 & 0.20 & 0.55 \\
\hline 50 & 4.1 & 157.3 & 10.3 & 123.0 & 14.9 & 4.6 & 2.0 & 0.20 & 0.56 \\
\hline 100 & 4.5 & 165.0 & 10.7 & 125.3 & 15.4 & 5.0 & 2.2 & 0.22 & 0.57 \\
\hline 150 & 4.7 & 169.3 & 11.1 & 130.0 & 15.7 & 5.2 & 2.4 & 0.23 & 0.60 \\
\hline SEm \pm & 0.09 & 1.31 & 0.12 & 0.88 & 0.11 & 0.15 & 0.08 & 0.006 & 0.020 \\
\hline$C(P=0.05)$ & 0.26 & 3.81 & 0.35 & 2.57 & 0.32 & 0.44 & 0.23 & 0.017 & NS \\
\hline \multicolumn{10}{|l|}{ FYM $\left(t^{2} a^{-1}\right)$} \\
\hline 0 & 3.7 & 152.5 & 9.5 & 119.7 & 14.6 & 4.3 & 1.8 & 0.18 & 0.53 \\
\hline 5 & 4.2 & 162.0 & 10.7 & 124.7 & 15.2 & 4.8 & 2.2 & 0.22 & 0.57 \\
\hline 10 & 4.8 & 165.7 & 11.3 & 129.5 & 15.7 & 5.3 & 2.4 & 0.24 & 0.61 \\
\hline SEm \pm & 0.08 & 1.14 & 0.10 & 0.77 & 0.09 & 0.13 & 0.07 & 0.005 & 0.017 \\
\hline $\mathrm{CD}(\mathrm{P}=0.05)$ & 0.23 & 3.31 & 0.29 & 2.24 & 0.26 & 0.38 & 0.20 & 0.014 & 0.049 \\
\hline
\end{tabular}

\section{Soil fertility}

Use of different levels of nitrogen and FYM caused a marked change in the organic carbon content in post harvest soil. The maximum amount of soil organic carbon (4.7 and $4.8 \mathrm{~g} \mathrm{~kg}^{-1}$ ) in post harvest soil was noted with $150 \mathrm{~kg} \mathrm{~N} \mathrm{ha}^{-1}$ and $10 \mathrm{t} \mathrm{FYM} \mathrm{ha}^{-1}$, respectivity. This increase in organic carbon content may be attributed to addition of FYM. The available $\mathrm{N}$ status exhibited marked difference due to various levels of nitrogen and FYM and highest values (169.3 and $165.7 \mathrm{kgha}^{-1}$ ) were obtained under $150 \mathrm{~kg} \mathrm{~N}^{-1}$ and $10 \mathrm{t}$ FYM ha ${ }^{-1}$, respectively. The lowest available nitrogen content was recorded in control treatments. Available phosphorus status recorded significant variation due to treatments (Table 3 ). Highest available $P$ content of 11.1 and $11.3 \mathrm{kgha}^{-1}$ was recorded in $150 \mathrm{~kg} \mathrm{~N}$ and $10 \mathrm{t} \mathrm{FYM} \mathrm{ha}^{-1}$, respectively. The lowest available $P$ content $(9.8$ and $9.5 \mathrm{~kg} \mathrm{ha}^{-1}$ ) was observed under controls, respectively. Application of $150 \mathrm{~kg} \mathrm{~N} \mathrm{ha}^{-1}$ and 10 $\mathrm{t} \quad \mathrm{FYM} \mathrm{ha}^{-1}$ showed significantly higher amount of available potassium in post harvest soil. The lowest available potassium content (120.3 and $119.7 \mathrm{~kg}$ $\mathrm{ha}^{-1}$ ) was recorded in control treatment. Available $S$ content in post harvest soil ranged from 14.6 to $15.7 \mathrm{~kg} \mathrm{ha}{ }^{-1}$ with $150 \mathrm{~kg} \mathrm{~N}$. Application of $10 \mathrm{t} \mathrm{FYM} \mathrm{ha}^{-1}$ also increased the amount of available $S$ in post harvest soil. Available $\mathrm{Fe}, \mathrm{Mn}$ and $\mathrm{Cu}$ content in soil tended to increase with $\mathrm{N}$ application but the status of zinc in soil was not affected significantly with applied N. On the other hand all the four 
micronutrient cations improved in soil with FYM application. The maximum values of these micronutrients were recorded under 10t FYM ha 1. The lowest values of DTPA Fe, Mn, Cu and $\mathrm{Zn}$ $\left(4.3,2.0,0.20,0.55 \mathrm{mgkg}^{-1}\right)$ in post harvest soil were recorded under control, respectively. Pandey (2018) and Goswami and Pandey (2018) reported similar results.

\section{REFERENCES}

Chesnin, L. and Yien, C.H. (1951) Turbidimetric determination of available sulphates. Proceedings of Soil Science Society of America 15: 149-151.

Goswami, R.K. and Pandey, M. (2018) Effect of integrated use of nutrients and FYMon yield, quality and uptake of nutrients by barley (Hordeum valgare). Annals of Plant and Soil Research 20 (4): 422-427.

Hanway, J.J. and Heidel, H. (1952) Soil analysis methods as used in lowa State College Soil testing Laboratory.lowa. Agric. 57: 1 $-31$.

Jackson M.L. (1973) Soil Chemical Analysis.Pentice Hall of India Pvt. Ltd., NewDelhi.

Kumar, Y., Singh, S.P. and Singh, V.P. (2015) Effect of FYM and potassium on yield nutrient uptake and economics of wheat in alluvial soil.Annals of Plant and Soil Research17 (1): 100-103.

Lindsay, W.L. and Norvell, W.A. (1978) Development of a DTPA test for $\mathrm{Zn}, \mathrm{Fe}$, $\mathrm{Mn}$ and $\mathrm{Cu}$. Soil Science Society of America Journal 42:421-28.

Olsen, S.R, Cole, G.V., Watanable, F.S. and Dean, L.A. (1954) Estimation of available phosphorus in soils extraction with sodium bicarbonate. Cire.U.S. Dept. Agric. 939

Pandey, M. (2018) Effect of integrated nutrient management on yield, quality and uptake of nutrients in oat (Avena sativa) in
It may be concluded from the present investigation that application of $150 \mathrm{~kg} \mathrm{~N}^{-1}$ and $10 \mathrm{t} \mathrm{FYM} \mathrm{ha}^{-1}$ proved beneficial under semiarid condition of Agra region of Uttar Pradesh for achieving higher productivity of oat crop, besides improving quality of produce and maintaining soil fertility.

alluvial soil.Annals of Plant and Soil Research.20 (1): 1-6.

Pandey, M. and Singh, O.P. (2017) Effect of balanced use of nutrients on yield, quality and uptake of nutrients by wheat (Triticum aestivum).Annals of Plant and Soil Research 19(4):426-429.

Pandey, M, Kumar, Surjit and Singh, U.N. (2020) Effect of integrated nutrient management on

productivity of oat (Avena sativa L.) and soil fertility. Annals of Plant and Soil Research 22 (2):151-155.

Sikarwar, B.P.S., Gupta, D.D. and Singh, L.P. (2018) Effect of varying nitrogen levels and varieties on productivity and profitability of wheat (Triticum aestivium) under rainfed condition. Annals of Plant and Soil Research 20 (1): 58-62

Singh, A.P., Pal, A.K. and Singh, A.P. (2016) Effect of FYM, potassium and zinc on yield, quality and uptake of nutrients in forage oat in alluvial soil. Annals of Plant and Soil Research 18 (4): 338-341.

Singh, V. and Patra, A. (2017) Effect of FYM and manganese on yield and uptake of nutrients in wheat (Triticum aestivum).Annals of Plant and Soil Research 19(4): 381-384.

Subbiah, B.V. and Asija, G.L. (1956) A rapid procedure for the estimation of available nitrogen in soils. Current Science 25: 259 -260 . 